\title{
NOISE LEVEL STUDY AND ASSESSMENT IN THE SOUTHERN PART OF PANEVÉŽYS
}

\author{
Pranas Baltrènas $^{1}$, Egidijus Petraitis $^{2}$, Tomas Januševičius ${ }^{3}$ \\ ${ }^{1,2,3}$ Dept of Environmental Protection, Vilnius Gediminas Technical University, \\ Sauletekio al. 11, LT-10223 Vilnius, Lithuania \\ E-mails: ${ }^{1}$ pbalt@vgtu.lt; ${ }^{2}$ egipet@vgtu.lt; ${ }^{3}$ jtomas@vgtu.lt
}

Submitted 22 Sept. 2008; accepted 15 Dec. 2009

\begin{abstract}
Noise is a relevant problem faced not only by Lithuania but across the world. With motor traffic flow increase, the noise caused by them is also growing and in particular noisy are heavy vehicles and motorcycles. Noise measurements were taken near the main streets in the southern part of Panevėžys. Measurements were made during three time periods of the day: in the daytime (from 6 a.m. to 6 p.m.), in the evening (from 6 p.m. to 10 p.m.) and at night (from 10 p.m. to 6 a.m.). In this part of the city noise is mainly generated by cars. The measured noise levels were compared with the noise level limit (NLL) in the measurement places where the NLL is most often exceeded. Noise level analysis and traffic flows are presented in the work. As the performed measurements show, the NLL in the daytime was exceeded by $65 \%$, in the evening by $88 \%$, and at night by $71 \%$ of all the total measurements made. The equivalent NLL was exceeded by up to $14 \mathrm{dBA}$ and the maximum NLL - by up to $17 \mathrm{dBA}$. The highest excess of the NLL was recorded by streets with the heaviest traffic.
\end{abstract}

Keywords: traffic noise, noise level in the living environment, noise level limit (NLL).

\section{Introduction}

In Lithuania, as in other countries, efforts are made to reduce the surrounding noise and avoid its adverse impact on human health and the quality of the environment (Ustinavičienè et al. 2004).

In most towns, the average noise increase is $1-3 \mathrm{~dB}$ per year (Gražulevičienè et al. 2003). The noise level is forecast to double in 15 years (Grubliauskas and Butkus 2004).

The main noise sources are generated by traffic on streets where in some cases motor traffic accounts for up to $80 \%$ of the total noise level in the territories of cities (Žeromskas 1998). The main cause of noise is an increasing number of old technically disorderly cars and continuously expanding activities of motor transport companies. Over the last 10 years the traffic in Lithuania increased 2.4 times. Due to the afore-mentioned reasons, the number of road accidents grew, car queues became longer and more time is spent at crossings, whereas all that resulted in increased environmental pollution with vehicle exhaust gas and noise generated by motor vehicles (Henckens et al. 2000).

Many town citizens suffer from the traffic-generated noise. Traffic is the most prevailing source of noise in towns (Grubliauskas and Butkus 2007). Traffic-generated noise accounts for $60-80 \%$ of the noise prevailing in towns. It has a negative effect in all the territories of towns: residential areas, hospitals, sanatoriums, recreation areas, town centres, utility and industrial territories (Kindurytė and Oškinis 2003).
The boundary of Panevėžys southern part stretches over Pušalotas, Nemunas, Klaipėda, Vilnius, and Basanavičius streets and the river of Nevěžis. The southeastern part of Panevėžys is dominated by dwelling houses and 5-storied buildings. The south central part, like the entire southern part, is dominated by high-rise dwellings. Locations away from the city centre are dominated by industrial objects. Multi-storied dwelling houses and collective garden areas without bustling streets are prevailing in the south-western part.

The aims and tasks of the work are to determine the distribution of noise levels among zones and compare them with the noise level limit (NLL), to determine measurement places where the NLL is exceeded most often and analyse the causes predetermining the NLL excess.

\section{Investigation methods}

Measurements of the traffic-generated noise are taken in the territories within the zone of influence of the trafficgenerated noise. Noise measurements were taken at the selected locations of Panevėžys town which are the most suitable for the characterisation of the environmental acoustics addressed. The measurement locations are selected considering the amount and speed of passing traffic in different sections of streets, street paving, the background noise of the area, the vegetation and the development of the area. The places and number of noise measurement locations depend on the investigated environment and spatial spread of noise within it. 


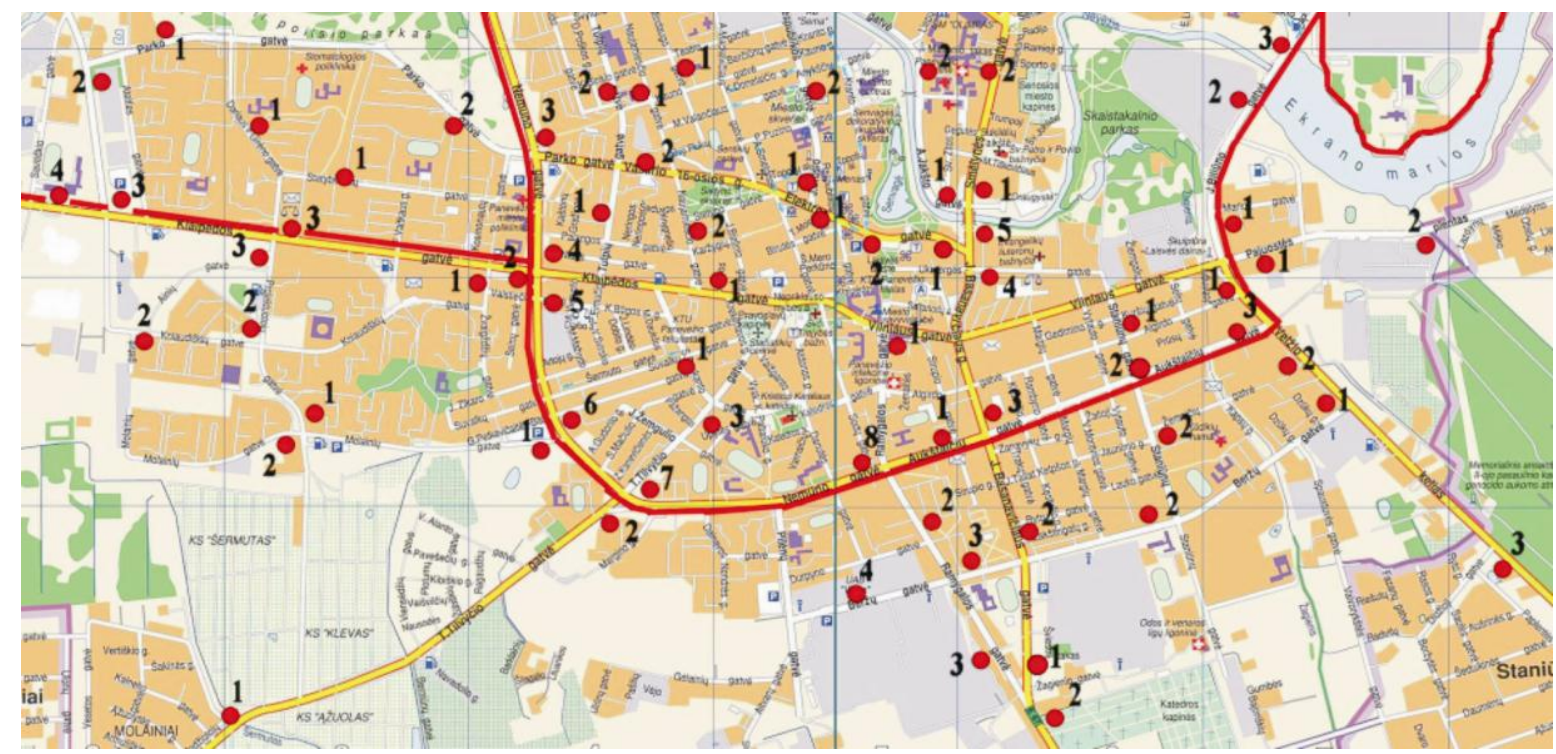

Fig. 1. Measurement location layout in Panevèžys town

In order to establish the levels of traffic-generated noise at different periods of the day, measurements were taken at each of the six measurement locations at a different time of the day: in the daytime (from 6 a.m. to 6 p.m.), in the evening (from 6 p.m. to 10 p.m.) and at night (from 10 p.m. to 6 a.m.). Fig. 1 shows six measurement locations where noise measurements are made within twenty four hours by measuring traffic-generated noise levels for 15 minutes each hour.

Motor traffic-generated noise was measured in the period of April, May and June and in autumn (September-October). Traffic in the town is the heaviest during the afore-mentioned periods. In addition, noise measurement during the cold season of the year under complicated weather conditions is impossible. It cannot be done when it's snowing, raining, when there is mist or the wind speed exceeds $5 \mathrm{~m} / \mathrm{s}$. When the wind speed is from 1 to $5 \mathrm{~m} / \mathrm{s}$, a microphone is covered with a special shield. Noise measurements are carried out when the relative humidity is not higher than $80 \%$ and air temperature is from $0{ }^{\circ} \mathrm{C}$ to $30{ }^{\circ} \mathrm{C}$.

Considering the development of the area and the peculiarities of noise dispersion, distances from the noise source to the measurement location can be adjusted. In territories that are closer than 7.5 metres from the axial trajectory line of a vehicle the noise is measured at place that is at 1- or 2- meter distance from the house wall, at a height of $4 \mathrm{~m}$ from the territory's surface by turning the microphone towards the source of noise.

Prior to and after taking measurements, the device is calibrated according to an instructive manual. If the calibration results differ by more than $2 \mathrm{dBA}$, the noise measurements are repeated.

When measuring the noise level with a precision of Bruel \& Kjaer mediator 2260, the relative measurement error is $\pm 1.5 \%$.

Prior to making noise level measurements, the meteorological conditions are determined: the relative air humidity, air temperature and wind speed. These data determine whether the measurements can be performed.

\section{Investigation results and analysis}

Velžis street (Fig. 2) is one of the town's main streets used to access the town from Anykščiai direction. This four-lane street is loaded with heavy car and vehicle flows. Cars drive along the street at a speed of around $60 \mathrm{~km} / \mathrm{h}$. In the daytime the equivalent noise level limit (NLL) was exceeded by $5 \mathrm{dBA}$ in the $1^{\text {st }}$ measurement location and by $8 \mathrm{dBA}$ in the $2^{\text {nd }}$ one; a high NLL excess in the $2^{\text {nd }}$ measurement location was predetermined by the traffic of 1020 cars and 98 heavy vehicles within the measurement time.

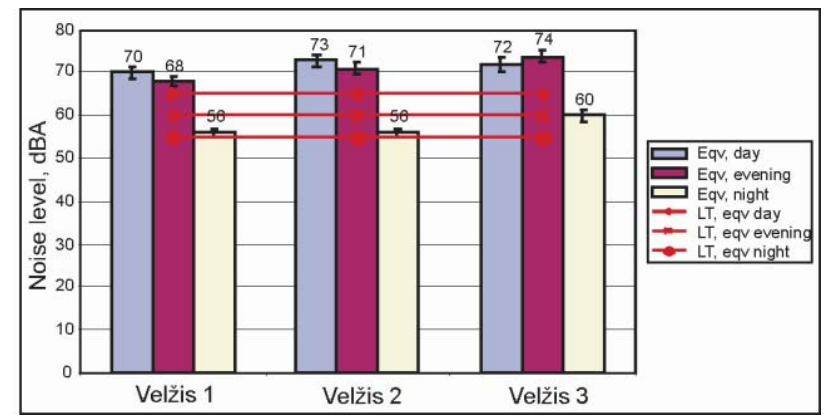

Fig. 2. Dynamics of equivalent noise levels in Velžis street within twenty four hours

In the evening the highest excess of the equivalent noise level, $14 \mathrm{dBA}$, was recorded in the $3^{\text {rd }}$ measurement location which was passed by 1101 cars and 62 heavy vehicles during the time of measurement. In the evening the highest excess of the equivalent noise level, $5 \mathrm{dBA}$, was recorded in the $3^{\text {rd }}$ measurement location which was passed by 659 cars and 40 heavy vehicles during the time of measurement. The lowest noise level was recorded in the $1^{\text {st }}$ measurement location which was passed by 714 cars and 66 heavy vehicles in the daytime, 646 cars and 55 heavy vehicles in the evening, and 589 cars and 41 heavy vehicles at night.

In Velžis street (Fig. 3), in the daytime the maximum NLL was exceeded by $15 \mathrm{dBA}$ in the $3^{\text {rd }}$ measurement location, in the evening the maximum NLL was exceeded 


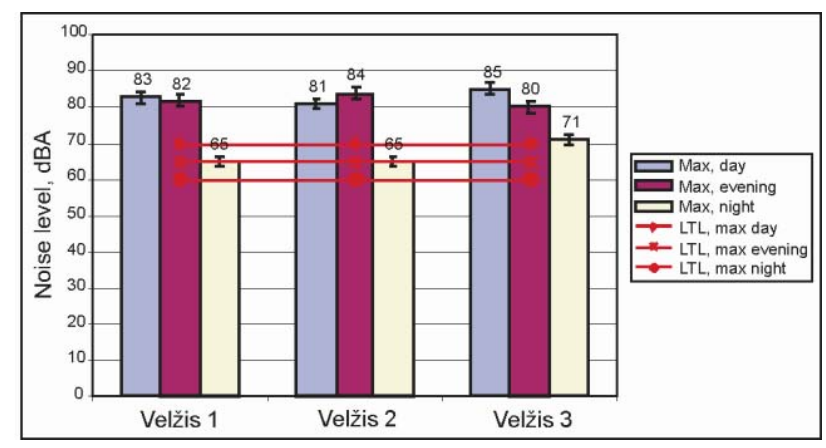

Fig. 3. Dynamics of maximum noise levels in Velžis street within twenty four hours

by up to $19 \mathrm{dBA}$, and at night the maximum NLL was exceeded by up to $11 \mathrm{dBA}$.

Beržai street is a two-lane street where four measurement places were selected. In the daytime the equivalent NLL was exceeded by $2 \mathrm{dBA}$ in the $1^{\text {st }}$ measurement location and by $3 \mathrm{dBA}$ in the $3^{\text {rd }}$ measurement location where the noise level was predetermined by the traffic of 940 cars and 46 heavy vehicles.

In the evening the highest equivalent NLL excess, $12 \mathrm{dBA}$, was recorded in the $4^{\text {th }}$ measurement location. A high excess of the NLL was predetermined by the traffic of 811 cars and 57 heavy vehicles. The traffic of 890 cars and 37 heavy vehicles predetermined the NLL excess of $10 \mathrm{dBA}$ in the $1^{\text {st }}$ measurement location.

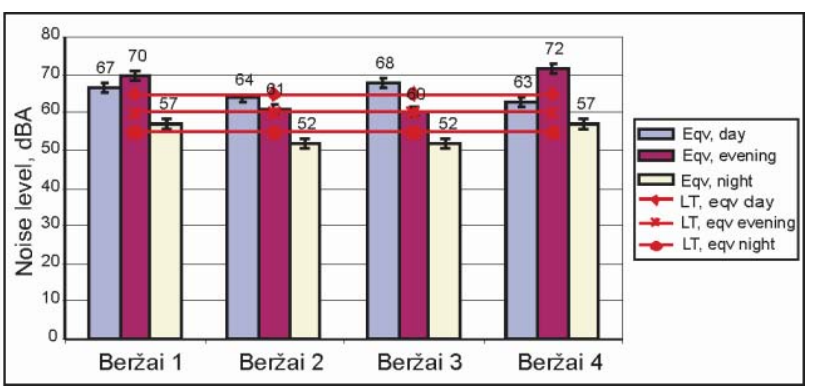

Fig. 4. Dynamics of equivalent noise levels in Beržai street within twenty four hours

In Beržai street (Fig. 4), at night the NLL was higher by $2 \mathrm{dBA}$ in the $1^{\text {st }}$ and $4^{\text {th }}$ measurement locations. These measurement locations were passed by the maximum of 433 cars and 14 heavy vehicles at the time of taking measurements.

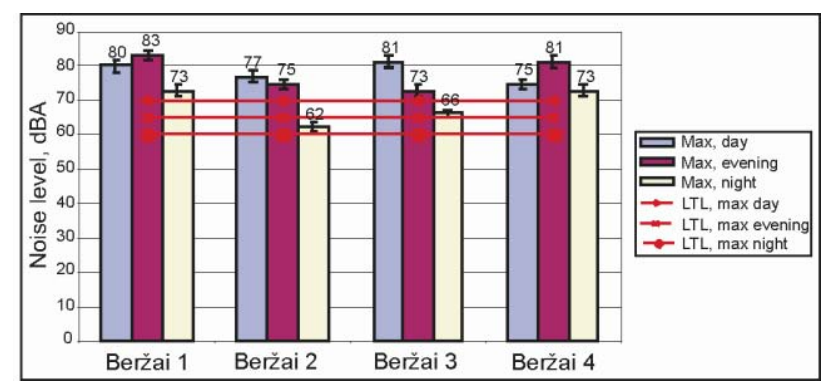

Fig. 5. Dynamics of maximum noise levels in Beržai street within twenty four hours
In Beržai street (Fig. 5), in the daytime the maximum NLL was exceeded by up to $11 \mathrm{dBA}$, in the evening the maximum NLL was exceeded by up to $18 \mathrm{dBA}$, and at night the maximum NLL was exceeded by up to 13 dBA.

In Ramygala street (Fig. 6), the $3^{\text {rd }}$ and $4^{\text {th }}$ measurement locations are in a one-way traffic section with slower and less intense traffic and the NLL was not exceeded in these measurement locations. The first 2 measurement locations are distinguished by heavier traffic with 1060 and 993 cars, and 102 and 111 heavy vehicles having passed them, where the NLL was exceeded by $6 \mathrm{dBA}$ and $8 \mathrm{dBA}$, respectively.

In the evening, Ramygala street had the traffic of 1058 cars and 87 heavy vehicles in the 1 st and 1168 cars and 92 heavy vehicles in the 2nd measurement locations; the NLL in the 1st measurement location was exceeded by $12 \mathrm{dBA}$, and in the 2 nd measurement location - by $14 \mathrm{dBA}$, while a high excess of the NLL was predetermined by a high traffic intensity.

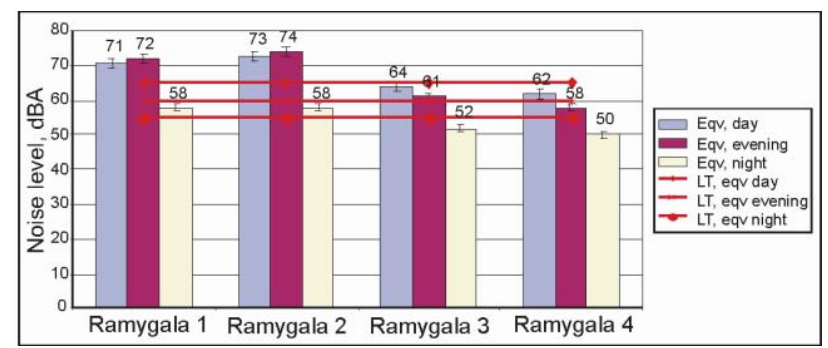

Fig. 6. Dynamics of equivalent noise levels in Ramygala street within twenty four hours

At night the NLL was exceeded by $3 \mathrm{dBA}$ only in the $1^{\text {st }}$ and $2^{\text {nd }}$ measurement locations, which was predetermined by the traffic of 234 and 239 cars, and 46 and 45 heavy vehicles, respectively; whereas in the $3^{\text {rd }}$ and $4^{\text {th }}$ measurement locations the NLL was not exceeded.

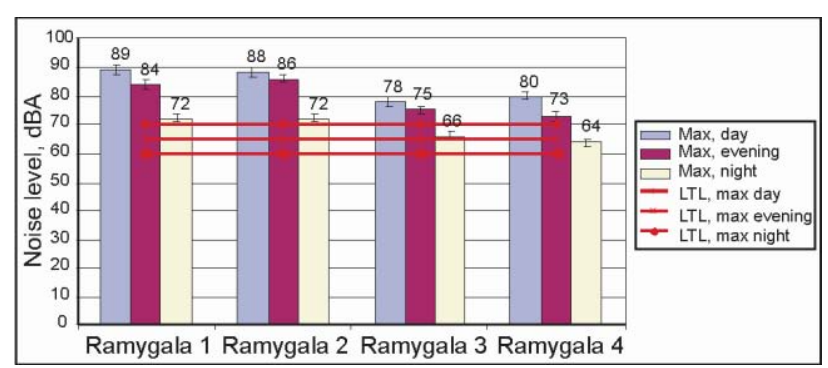

Fig. 7. Dynamics of maximum noise levels in Ramygala street within twenty four hours

In Ramygala street (Fig. 7), in the daytime the maximum NLL was exceeded by 8 to $29 \mathrm{dBA}$, in the evening the maximum NLL was exceeded by 8 to $21 \mathrm{dBA}$, and at night the maximum NLL was exceeded by $4 \mathrm{dBA}$ to $12 \mathrm{dBA}$.

In Tilvytis street (Fig. 8), the traffic flow is nearly the same in the daytime and in the evening, and the noise level recorded there in the daytime and in the evening differed only by $2 \mathrm{dBA}$. At night the NLL was exceeded by a maximum of $3 \mathrm{dBA}$ in the $1^{\text {st }}$ measurement location. 


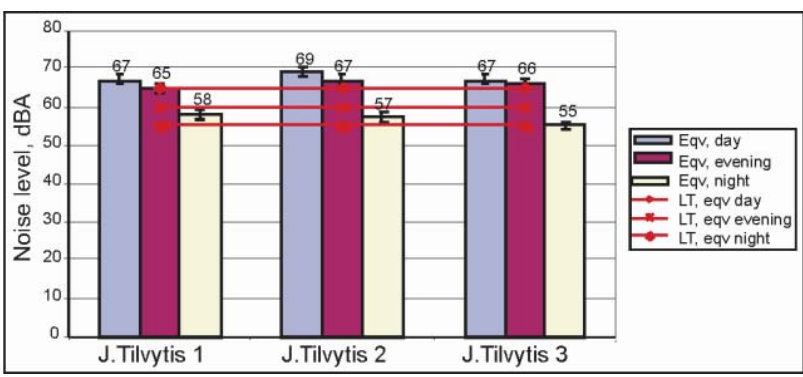

Fig. 8. Dynamics of equivalent noise levels in J. Tilvytis street within twenty four hours

During the daytime measurements the $1^{\text {st }}$ measurement location was passed by the biggest number of vehicles - 693 cars and 42 heavy vehicles, whereas during evening measurements it was passed by 462 cars and 25 heavy vehicles. During night measurements 81 cars and 11 heavy vehicles passed the $1^{\text {st }}$ measurement location.

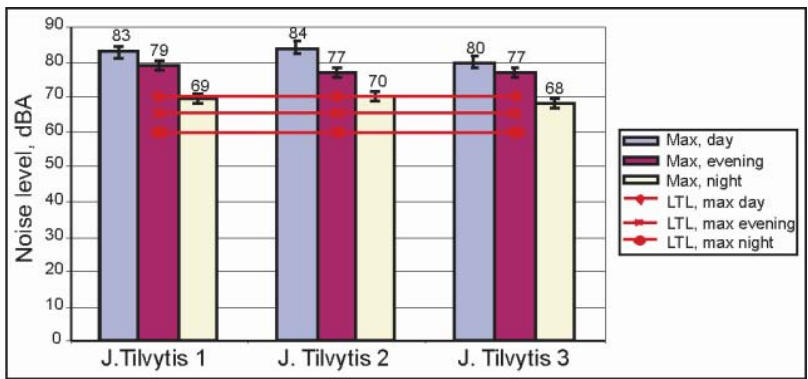

Fig. 9. Dynamics of maximum noise levels in J. Tilvytis street within twenty four hours

In Tilvytis street (Fig. 9), in the daytime the maximum NLL was exceeded by $13 \mathrm{dBA}$, in the evening the maximum NLL was exceeded by up to $14 \mathrm{dBA}$ and at night by $10 \mathrm{dBA}$.

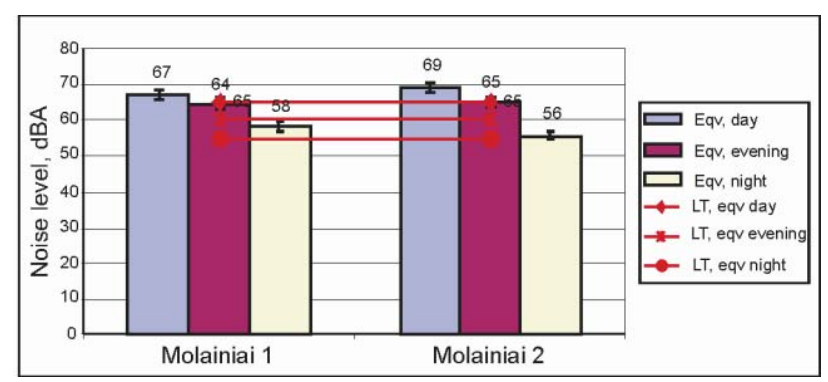

Fig. 10. Dynamics of equivalent noise levels in Molainiai street within twenty four hours

A four-lane Molainiai street (Fig. 10) stretches over a dwelling-house district and is not distinguished by a heavy traffic.

In the daytime the NLL was exceeded by $2 \mathrm{dBA}$ in the $1^{\text {st }}$ and by $4 \mathrm{dBA}$ in the $2^{\text {nd }}$ measurement locations. Such a noise level was predetermined by the traffic of 734 cars and 5 heavy vehicles in the $1^{\text {st }}$ and 680 cars and 4 heavy vehicles in the $2^{\text {nd }}$ measurement locations.

In the evening the NLL was exceeded by $4 \mathrm{dBA}$ in the $1^{\text {st }}$ and by $5 \mathrm{dBA}$ in the $2^{\text {nd }}$ measurement locations. The maximum NLL excess in both measurement locations was the result of the traffic of 625 and 619 cars and 3 and 4

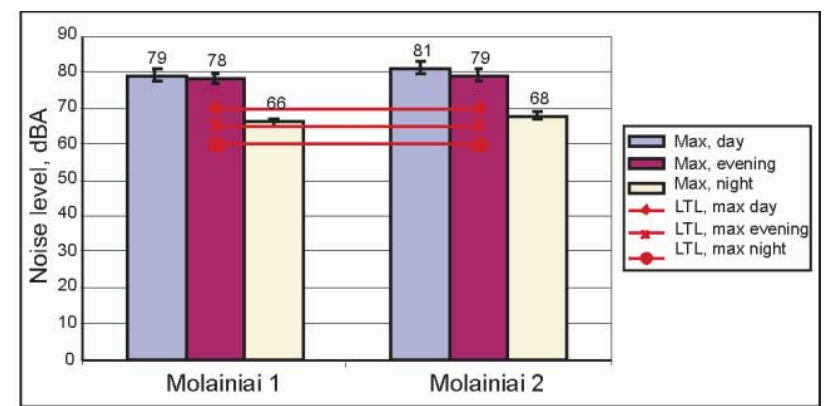

Fig. 11. Dynamics of maximum noise levels in Molainiai street within twenty four hours

heavy vehicles. Since the street stretches over a residential district, both the traffic flows and the noise generated by them are similar in the daytime and in the evening.

In Molainiai street (Fig. 11), in the daytime the maximum NLL was exceeded by 9 to $11 \mathrm{dBA}$, in the evening - by 13 to $14 \mathrm{dBA}$, and at night - by $6 \mathrm{dBA}$ to $8 \mathrm{dBA}$.

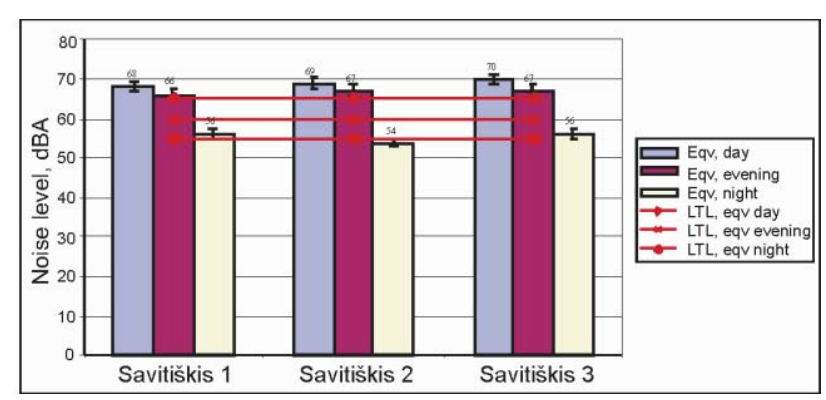

Fig. 12. Dynamics of equivalent noise levels in Savitiškis street within twenty four hours

Savitiškis street (Fig. 12) consists of two lanes separated by a grass-plot. Heavy traffic is not typical of this street. The traffic of 630 cars and 140 heavy vehicles in the $1^{\text {st }}$ measurement location during daytime measurements predetermined the excess of the NLL by $3 \mathrm{dBA}$; the traffic of 660 cars and 129 heavy vehicles resulted in the NLL excess of $4 \mathrm{dBA}$ in the $2^{\text {nd }}$ measurement location. The highest excess of the NLL, $5 \mathrm{dBA}$, was recorded in the $3^{\text {rd }}$ measurement location which was passed by 716 cars and 132 heavy vehicles. The level of noise in this street was increasing in proportion to increasing traffic.

In the evening the equivalent NLL was exceeded by $6 \mathrm{dBA}$ in the $1^{\text {st }}$ measurement location where the noise level was predetermined by the traffic of 516 cars and 123 heavy vehicles. In the $2^{\text {nd }}$ and $3^{\text {rd }}$ measurement locations the NLL was exceeded by $7 \mathrm{dBA}$ due to the traffic of 547 and 532 cars, and 119 and 125 heavy vehicles, respectively.

At night the equivalent NLL was exceeded by $1 \mathrm{dBA}$ only in the $1^{\text {st }}$ and $3^{\text {rd }}$ measurement locations where the noise level was predetermined by 384 and 422 cars, and 6 and 4 heavy vehicles, respectively.

In Savitiškis street (Fig. 13), in the daytime the maximum NLL was exceeded by 12 to $14 \mathrm{dBA}$, in the evening the maximum NLL was exceeded by 12 to $14 \mathrm{dBA}$, and at night the maximum NLL was exceeded by $5 \mathrm{dBA}$ to $10 \mathrm{dBA}$. 


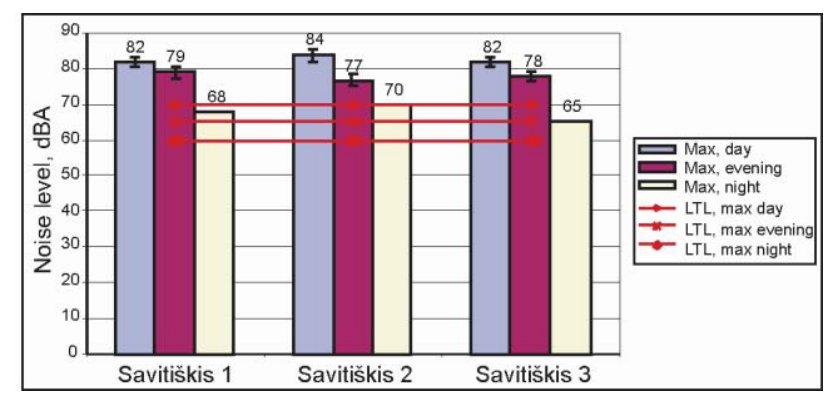

Fig. 13. Dynamics of maximum noise levels in Savitiškis street within twenty four hours

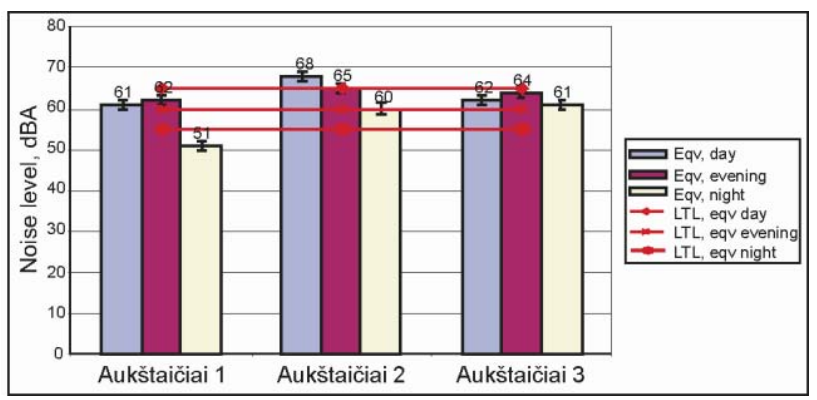

Fig. 14. Dynamics of equivalent noise levels in Aukštaičiai street within twenty four hours

A two-lane Aukštaičiai street (Fig. 14) stretches over a district of multi-apartment dwelling houses. Cars run along the street at a speed of around $50 \mathrm{~km} / \mathrm{h}$. The street is distinguished by a low traffic. In the daytime the equivalent NLL was exceeded by $3 \mathrm{dBA}$ only in the $2^{\text {nd }}$ measurement location due to 390 cars and 27 heavy vehicles having passed it; the 2 nd and $3^{\text {rd }}$ measurement locations were passed by 293 and 339 cars, and 34 and 51 heavy vehicles and the NLL was not exceeded there.

In the evening the noise level in the $1^{\text {st }}$ and $3^{\text {rd }}$ measurement locations was higher than in the daytime, and in the $2^{\text {nd }}$ measurement location, which was passed by 363 cars and 33 heavy vehicles, the NLL was exceeded by $5 \mathrm{dBA}$, and in the $3 \mathrm{rd}$, which was passed by 380 cars and 18 heavy vehicles, an excess of $4 \mathrm{dBA}$ was recorded.

At night the equivalent NLL was exceeded by $5 \mathrm{dBA}$ in the $2^{\text {nd }}$ measurement location and by $6 \mathrm{dBA}$ in the $3^{\text {rd }}$ measurement location. The noise level was predetermined by the traffic of 305 and 346 cars, and 22 and 20 heavy vehicles.

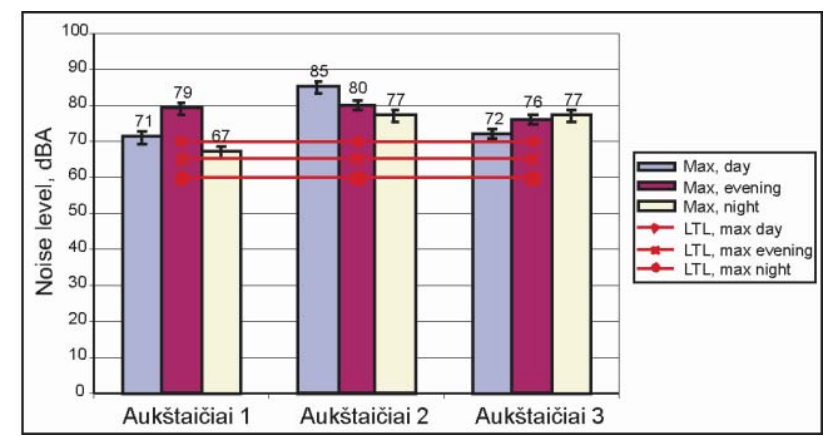

Fig. 15. Dynamics of maximum noise levels in Aukštaičiai street within twenty four hours
In Aukštaičiai street (Fig. 15) in the daytime and in the evening the maximum NLL was exceeded by $15 \mathrm{dBA}$, at night the maximum NLL was exceeded by 7 to $17 \mathrm{dBA}$.

In Projektuotojai street, in the daytime the equivalent NLL was not exceeded; the daytime noise level was predetermined by the traffic of 414 to 432 cars, and 20 to 31 heavy vehicles.

In the evening the equivalent NLL was exceeded by $5 \mathrm{dBA}$ in the $1^{\text {st }}$ measurement location due to the traffic of 441 cars and 25 heavy vehicles. In the $3^{\text {rd }}$ measurement location the NLL was exceeded by $4 \mathrm{dBA}$ due to the traffic of 427 cars and 16 heavy vehicles.

At night, in the 2nd measurement location the equivalent NLL was exceeded by $4 \mathrm{dBA}$ due to the traffic of 340 cars and 9 heavy vehicles. The equivalent NLL was exceeded by $5 \mathrm{dBA}$ in the 1 st and $3 \mathrm{rd}$ measurement locations where the noise level was predetermined by the traffic of 393 and 375 cars, and 13 and 15 heavy vehicles.

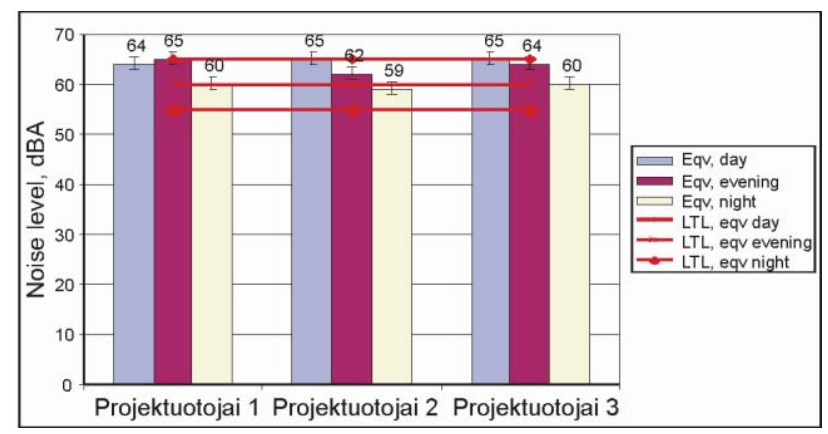

Fig. 16. Dynamics of equivalent noise levels in Projektuotojai street within twenty four hours

In Projektuotojai street (Fig. 16), in the daytime and in the evening the intensity of traffic is similar, the recorded noise level in the daytime reached 64-65 dBA not exceeding the equivalent NLL, and such a noise level in the daytime was predetermined by the traffic of 414 and 432 cars, and 20 to 31 heavy vehicles.

In the evening the noise level was nearly the same as in the daytime but upon the NLL decrease by $5 \mathrm{dBA}$ the NLL in the $1^{\text {st }}$ measurement location was exceeded by $5 \mathrm{dBA}$, which was predetermined by the traffic of 441 cars and 25 heavy vehicles. In the $3^{\text {rd }}$ measurement location the NLL was exceeded by $4 \mathrm{dBA}$ due to the traffic of 427 cars and 16 heavy vehicles.

At night, the equivalent NLL was exceeded by $4 \mathrm{dBA}$ in the $2^{\text {nd }}$ measurement location due to the traffic of 340 cars and 9 heavy vehicles, the equivalent NLL in the $1^{\text {st }}$ and $3^{\text {rd }}$ measurement locations was exceeded by $5 \mathrm{dBA}$ due to the traffic of 393 and 375 cars, and 13 and 15 heavy vehicles.

In Projektuotojai street (Fig. 17), in the daytime the maximum NLL was exceeded by 6 to $10 \mathrm{dBA}$, in the evening the maximum NLL was exceeded by 14 to $16 \mathrm{dBA}$, and at night the maximum NLL was exceeded by $12 \mathrm{dBA}$ to $17 \mathrm{dBA}$.

In Parkas street (Fig. 18), traffic is not heavy and the noise level is not high. 


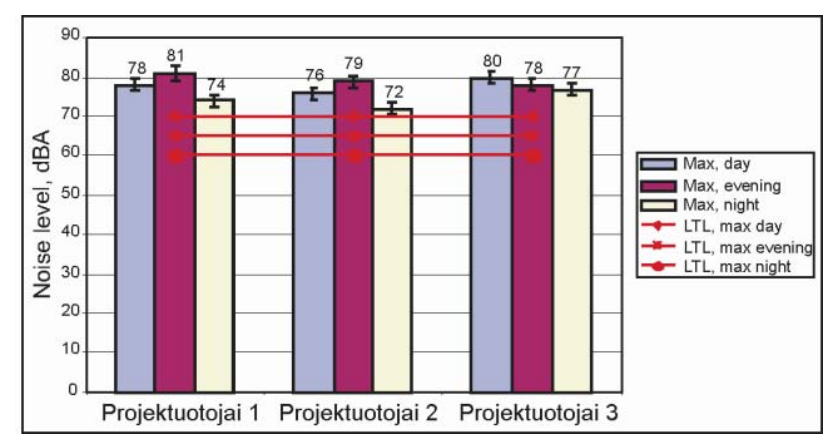

Fig. 17. Dynamics of maximum noise levels in Projektuotojai street within twenty four hours

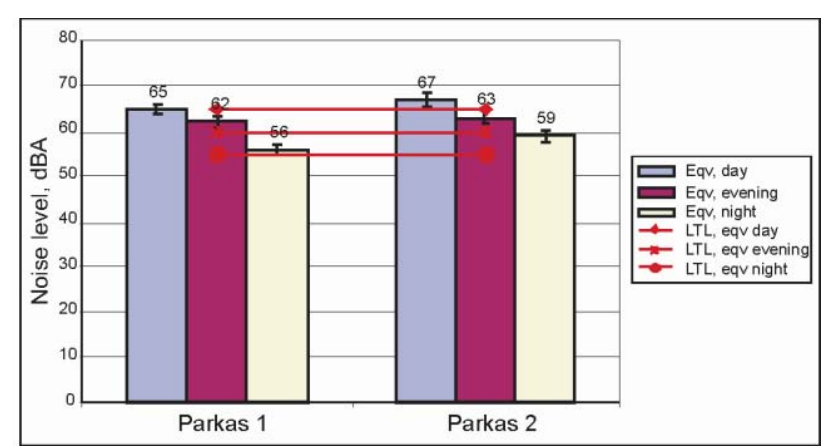

Fig. 18. Dynamics of equivalent noise levels in Parkas street within twenty four hours

In the daytime the equivalent NLL was exceeded by $2 \mathrm{dBA}$ in the $2^{\text {nd }}$ measurement location and in the evening the NLL was exceeded in both measurement locations.

In the evening the equivalent NLL was exceeded by $2 \mathrm{dBA}$ in the $1^{\text {st }}$ measurement location where the noise level was determined by the traffic of 405 cars and 14 heavy vehicles, and by $3 \mathrm{dBA}$ in the $2^{\text {nd }}$ measurement location due to the traffic of 311 cars and 15 heavy vehicles.

In the evening the equivalent NLL was exceeded by $1 \mathrm{dBA}$ in the $1^{\text {st }}$ measurement location where the noise level was determined by the traffic of 294 cars and 11 heavy vehicles, and by $4 \mathrm{dBA}$ in the $2^{\text {nd }}$ measurement location due to the traffic of 352 cars and 7 heavy vehicles. A higher noise level in the $2^{\text {nd }}$ measurement location was determined by a higher speed of cars.

In Parkas street (Fig. 19), in the daytime the maximum NLL was exceeded by 7 to $11 \mathrm{dBA}$, in the evening

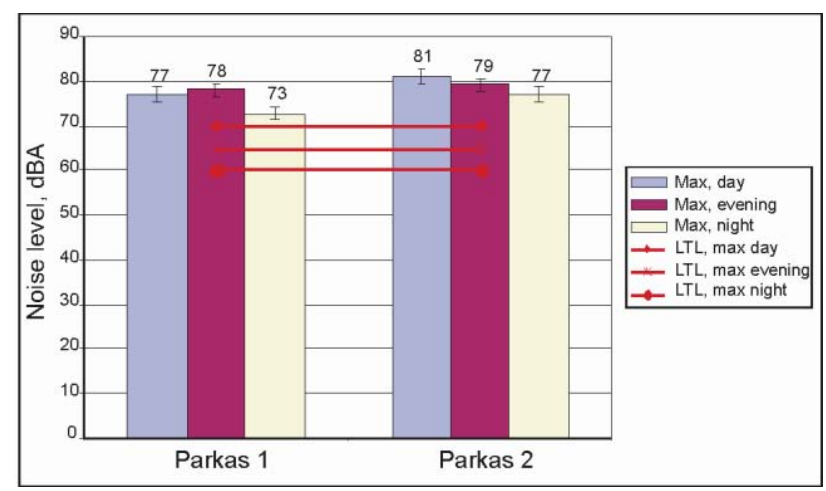

Fig. 19. Dynamics of maximum noise levels in Parkas street within twenty four hours the maximum was exceeded by 13 to $14 \mathrm{dBA}$, and at night the maximum NLL was exceeded by $13 \mathrm{dBA}$ to 17 dBA.

Biliūnas street (Fig. 20) differs from the other town streets by its four lanes separated by a grass-plot. Cars run along this street at a speed of $60 \mathrm{~km} / \mathrm{h}$. Three measurement locations were selected in this street. The recorded difference in noise levels in all the measurement locations during different time periods of the day was similar showing a mere difference of $1 \mathrm{dBA}$. In the daytime the equivalent NLL was exceeded by 1 to $2 \mathrm{dBA}$. The noise level was determined by the traffic of cars which varied from 797 to 841 cars and that of heavy vehicles - from 76 to 88 heavy vehicles during the period of measurement.

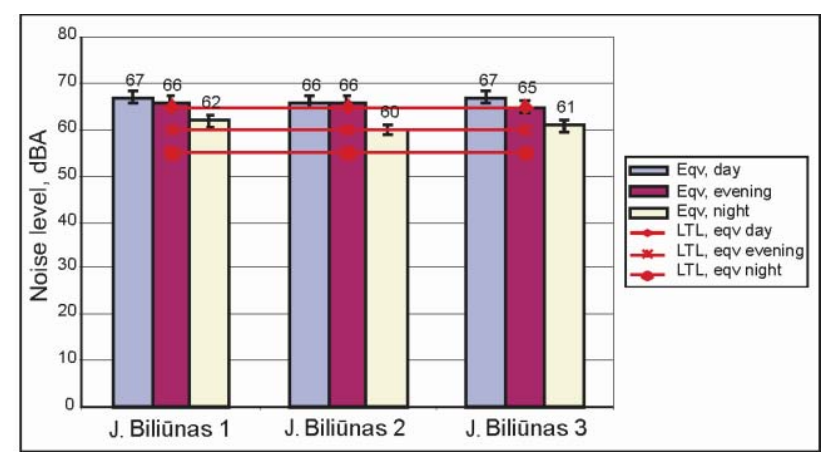

Fig. 20. Dynamics of equivalent noise levels in J. Biliūnas street within twenty four hours

In the evening the equivalent NLL was exceeded by 5 to $6 \mathrm{dBA}$, and the noise level in the daytime, like in the evening, was predetermined by a heavy traffic of cars and heavy vehicles. The traffic of cars was from 717 to 804 , and that of heavy vehicles - from 79 to 92 .

At night the NLL was exceeded by 5 to $7 \mathrm{dBA}$. The traffic of cars changed from 631 to 698 and that of heavy vehicles - from 52 to 71 .

In the evening and in the daytime the traffic of cars and the noise level generated by them nearly did not change.

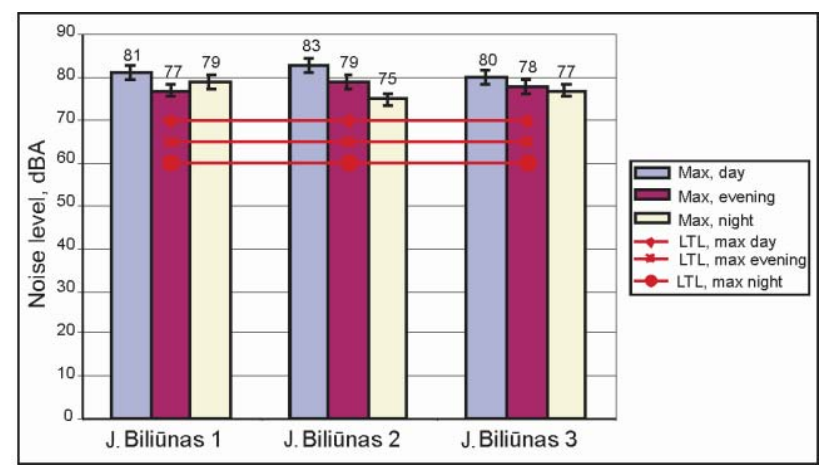

Fig. 21. Dynamics of maximum noise levels in J. Biliūnas street within twenty four hours

In Biliūnas street (Fig. 21), in the daytime the maximum NLL was exceeded by 10 to $13 \mathrm{dBA}$, in the evening the maximum NLL was exceeded by 12 to $14 \mathrm{dBA}$, and at night the maximum NLL was exceeded by $15 \mathrm{dBA}$ to $19 \mathrm{dBA}$. 


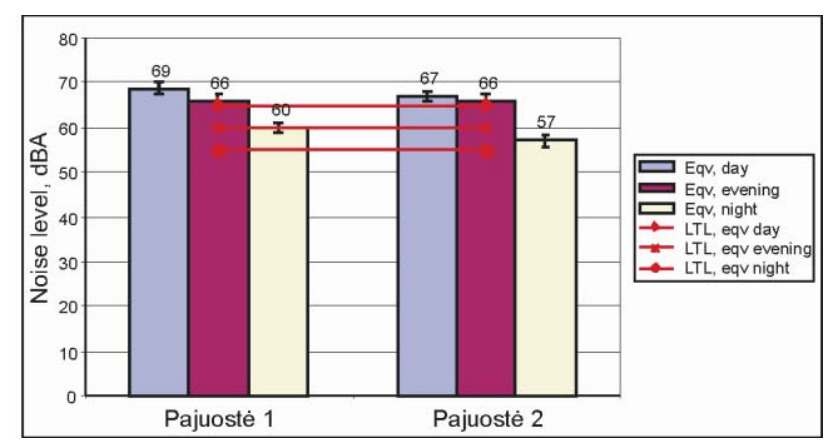

Fig. 22. Dynamics of equivalent noise levels in Pajuostè street within twenty four hours

In Pajuoste street (Fig. 22), in the daytime the equivalent NLL was higher by $4 \mathrm{dBA}$ in the $1^{\text {st }}$ and $2^{\text {nd }}$ measurement locations. A higher noise level was predetermined by the traffic of 360 cars and 44 heavy vehicles, whereas the noise level in the $2^{\text {nd }}$ location was predetermined by the traffic of 308 cars and 40 heavy vehicles.

The excess of the NLL by $6 \mathrm{dBA}$ in both measurement locations in the evening was predetermined by the traffic of 288 and 273 cars, and 35 and 41 heavy vehicles.At night the NLL was exceeded by 5 and $2 \mathrm{dBA}$. A higher excess of the NLL was recorded in the $1^{\text {st }}$ measurement location which was predetermined by the traffic of 257 cars and 23 heavy vehicles. The noise level in the $2^{\text {nd }}$ measurement location was predetermined by the traffic of 261 cars and 19 heavy vehicles.

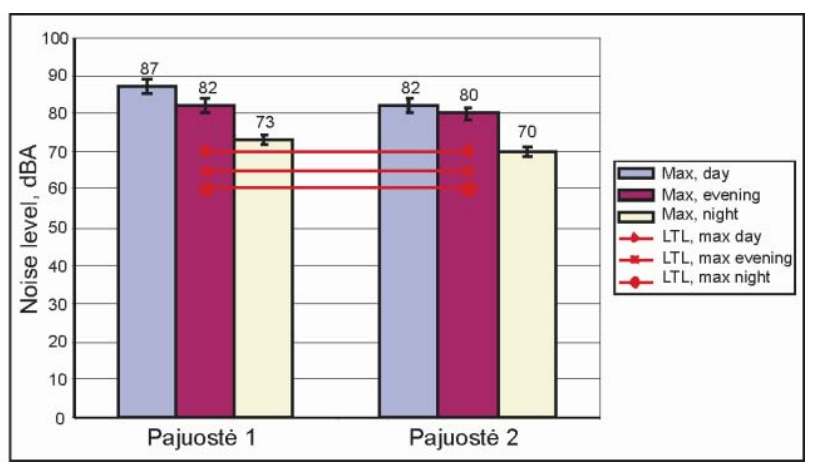

Fig. 23. Dynamics of maximum noise levels in Pajuostè street within twenty four hours

In Pajuoste street (Fig. 23), in the daytime the maximum NLL was exceeded by 12 to $17 \mathrm{dBA}$, in the evening the maximum NLL was exceeded by 15 to $17 \mathrm{dBA}$, and at night the maximum NLL was exceeded by $10 \mathrm{dBA}$ to $13 \mathrm{dBA}$.

Staniūnai street (Fig. 24) is a four-lane street stretching over district of dwelling-houses.

The equivalent NLL was not exceeded in the daytime in Staniūnai street.

The excess of the NLL by $2 \mathrm{dBA}$ in the evening in both measurement places was predetermined by the traffic of 233 and 231 cars, and 3 heavy vehicles.

At night the NLL was exceeded by $3 \mathrm{dBA}$ in the $1^{\text {st }}$ and by $1 \mathrm{dBA}$ in the 2 nd measurement locations. A higher excess of the NLL was recorded in the 1st measurement location which was predetermined by the traffic of

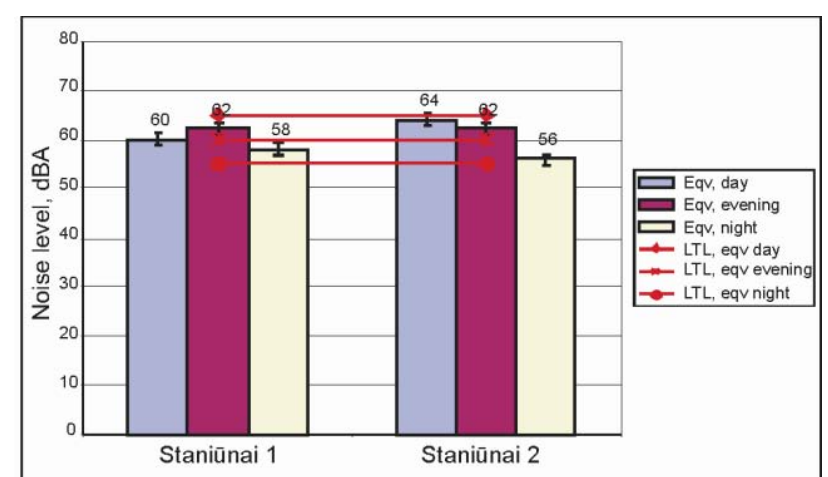

Fig. 24. Dynamics of equivalent noise levels in Staniūnai street within twenty four hours

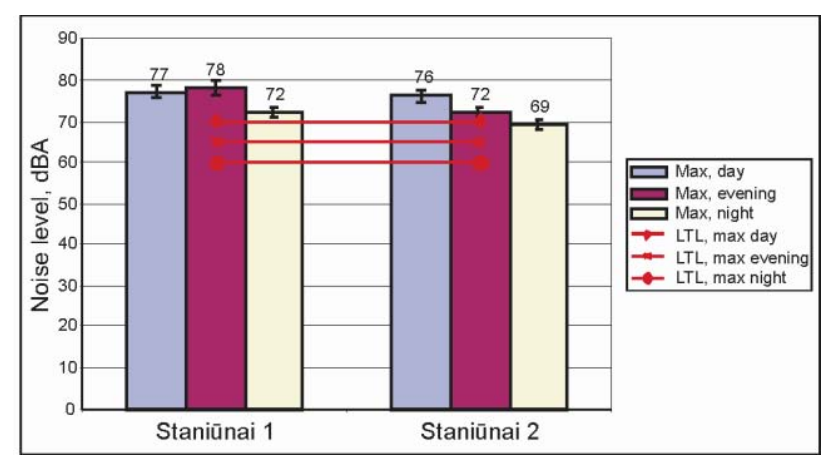

Fig. 25. Dynamics of maximum noise levels in Staniūnai street within twenty four hours

157 cars and 1 heavy vehicle. The noise level in the 2 nd measurement location was predetermined by the traffic of 114 cars.

In Staniūnai street (Fig. 25), in the daytime the maximum NLL was exceeded by 6 to $7 \mathrm{dBA}$, in the evening the maximum NLL was exceeded by 7 to $13 \mathrm{dBA}$, and at night the maximum NLL was exceeded by $9 \mathrm{dBA}$ to $12 \mathrm{dBA}$.

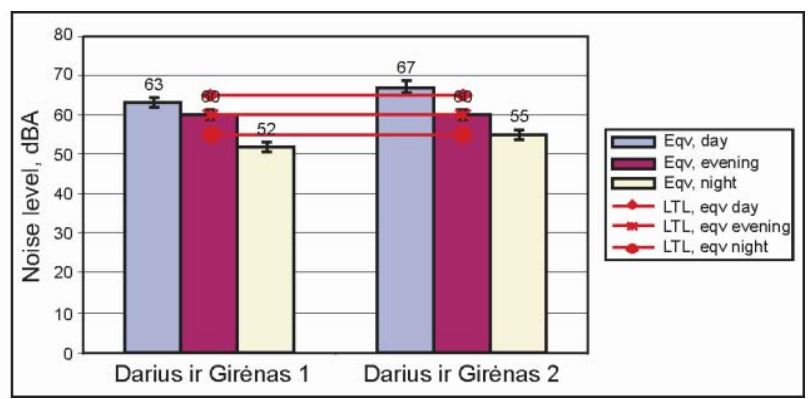

Fig. 26. Dynamics of equivalent noise levels in Darius and Girenas street within twenty four hours

In Darius ir Girènas street (Fig. 26), in the daytime the equivalent NLL was exceeded by $2 \mathrm{dBA}$ only in the $2^{\text {nd }}$ measurement location, which was predetermined by the traffic of 492 cars and 31 heavy vehicles.

The noise level in the evening was predetermined by the traffic of 224 and 230 cars, and 19 and 25 heavy vehicles, but the NLL was not exceeded.

At night the equivalent NLL was not exceeded.

In Darius ir Girènas street (Fig. 27), in the daytime the maximum NLL was exceeded by 4 to $11 \mathrm{dBA}$, in the evening the maximum NLL was exceeded by 8 to $12 \mathrm{dBA}$, and 


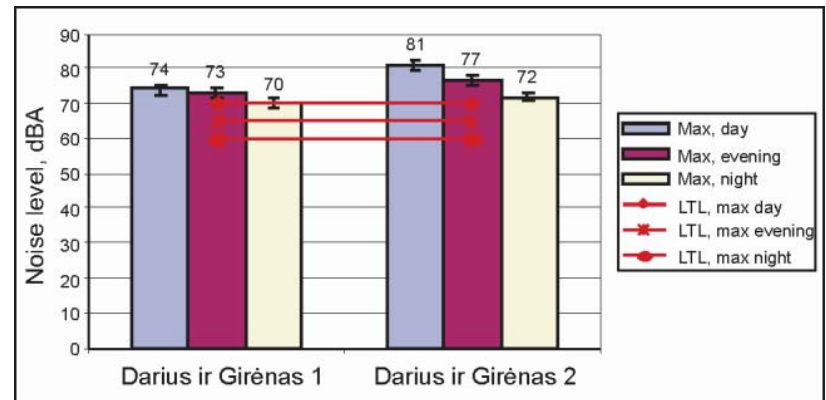

Fig. 27. Dynamics of maximum noise levels in Darius ir Girenas street within twenty four hours

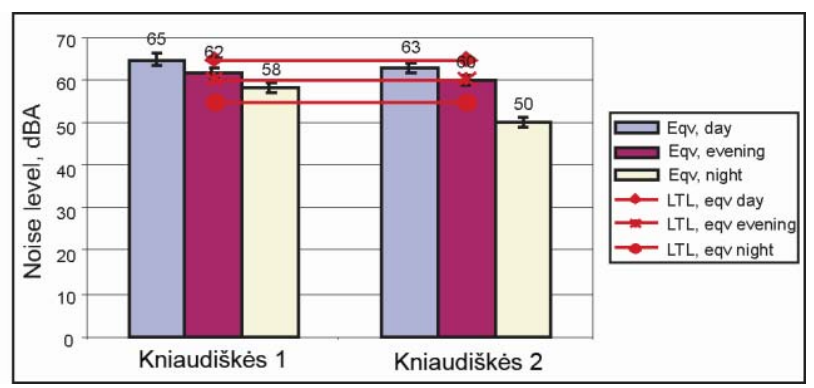

Fig. 28. Dynamics of equivalent noise levels in Kniaudiškès street within twenty four hours

at night the maximum NLL was exceeded by $10 \mathrm{dBA}$ to $12 \mathrm{dBA}$.

In Kniaudiškès street (Fig. 28), in the daytime the equivalent NLL was not exceeded, and the noise level of the daytime was predetermined by the traffic of 342 and 300 cars, and 14 and 16 heavy vehicles.

In the evening the equivalent NLL was exceeded by $2 \mathrm{dBA}$ only in the $1^{\text {st }}$ measurement location where the noise level was predetermined by the traffic of 286 cars and 12 heavy vehicles.

At night, like in the evening, the equivalent NLL was exceeded by $3 \mathrm{dBA}$ only in the $1^{\text {st }}$ measurement location where the noise level was predetermined by the traffic of 251 cars and 5 heavy vehicles.

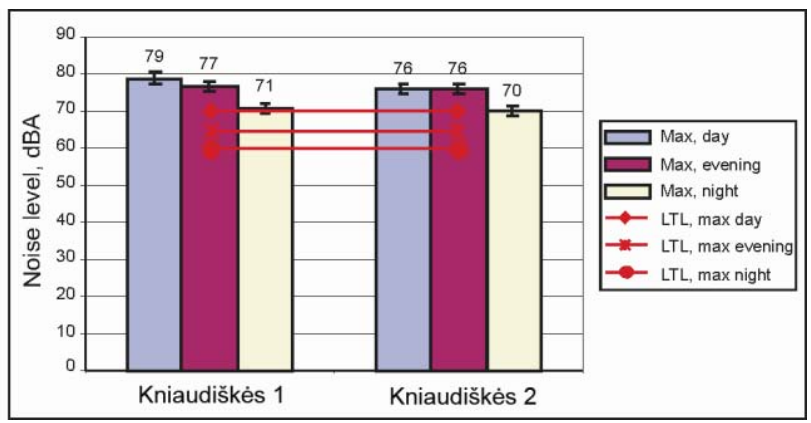

Fig. 29. Dynamics of maximum noise levels in Kniaudiškès street within twenty four hours

In Kniaudiškès street (Fig. 29) in the daytime the maximum NLL was exceeded by up to $9 \mathrm{dBA}$, in the evening the maximum NLL was higher by up to $12 \mathrm{dBA}$, and at night the maximum NLL was exceeded by up to $11 \mathrm{dBA}$.

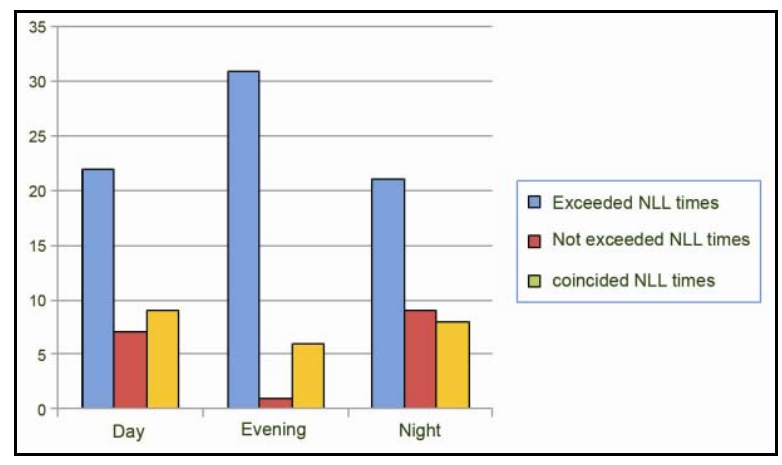

Fig. 30. The number of instances when the NLL was exceeded, non-exceeded and satisfied during all noise measurements in the daytime, in the evening and at night

Generalization of the measurement results is presented in Fig. 30. Measurements were taken in 38 measurement locations. In the daytime the equivalent NLL was exceeded in 22 instances, at night the NLL was exceeded in 21 instance, whereas the NLL was exceeded most often, in 31 out of 38 instances, in the evening. The noise level often is the same in the daytime and in the evening.

The noise level did not exceed the NLL 7 times in the daytime, 9 times at night and only 1 time in the evening.

The equivalent noise level recorded in the daytime in 9 instances satisfied the NLL, the noise level in the evening in 6 instances satisfied the NLL and that at night - only in 1 instance.

\section{Conclusions}

1. The measurement of dynamics of the noise level in the daytime, in the evening and at night in the southern part of Panevezzys shows that the recorded excess of the noise level limit (NLL) accounted for $65 \%$ in the daytime, $88 \%$ in the evening and $71 \%$ at night of the total measurements.

2. The highest NLL excess was recorded in streets with heavier traffic of cars and heavy vehicles.

3. The maximum noise level in the daytime normally reached $80-85 \mathrm{dBA}$ exceeding the NLL by 10-15 dBA; the maximum noise level recorded in the evening reached $75-79 \mathrm{dBA}$ exceeding the NLL by $10-14 \mathrm{~dB}$, and at night the maximum noise level in the majority of measurement locations reached $77 \mathrm{dBA}$ exceeding the NLL by up to $17 \mathrm{dBA}$.

4. In the southern part of Panevėžys the highest excess of the equivalent NLL in the daytime was recorded in Velžis and Ramygala streets where the NLL was exceeded by up to $8 \mathrm{dBA}$, in the evening the highest excess of the NLL was recorded in Velžis and Ramygala streets where the NLL was higher by up to $14 \mathrm{dBA}$, and the highest excess of the NLL at night was recorded in Ramygala and Pajuoste streets where the NLL was exceeded by up to $5 \mathrm{dBA}$. 


\section{References}

Baltrènas, P.; Butkus, D.; Grubliauskas, R. 2008. Experimental research into the dispersion of railway traffic noise in the environment and its modeling, Ecology 54(2): 9-15.

Baltrènas, P.; Fröhner, K.; Puzinas, D. 2007. Jūrų uosto ịrenginių triukšmo sklaidos įmonès ir gyvenamojoje teritorijoje tyrimai, Journal of Environmental Engineering and Landscape Management 15(2): 85-92.

Butkus, D.; Grubliauskas, R. 2008. Investigation of noise level in Trakai city during day, in 7-th International conference "Environmental Engineering". Environmental protection section. Vilnius: Technika, 85-92.

Gražulevičienè, R.; Lekavičiūtė, J.; Mozgeris, G.; Merkevičius, S. 2003. Autotransporto srautų keliamas triukšmas ir sergamumas miokardo infarktu Kauno mieste, Aplinkos tyrimai, inžinerija ir vadyba 1(23): 70-75.

Grubliauskas, R.; Butkus, D. 2004. Autotransporto triukšmo žiemą magistralëje Kaunas - Zarasai ịvertinimas, iš 7-osios Lietuvos jaunuju mokslininku konferencijos „Lietuva be mokslo - Lietuva be ateities", ivykusios Vilniuje $2004 \mathrm{~m}$. kovo 25 d., pranešimu medžiaga. Aplinkos apsaugos inžinerija. Vilnius: Technika, 338-346.

Grubliauskas, R.; Butkus, D. 2007. Geležinkelio transporto keliamo triukšmo stotyse tyrimai, iš 10-osios Lietuvos jaunuju mokslininku konferencijos „Mokslas - Lietuvos ateitis" pranešimu medžiaga. Aplinkos apsaugos inžinerija. Vilnius: Technika, 315-323.

Henckens, T.; Nooteboom, S.; Švarplienè, A. 2000. Transportas ir aplinka - daugiašalis požiūris: subalansuotos plètros Centrinès ir Rytų Europos šalyse link, Aplinkos inžinerija [Environmental Engineering] 8(4): 248-254.
Kindurytė, R.; Oškinis, V. 2003. Autotransporto triukšmo poveikis gyventojų sveikatai, iš 6-osios Lietuvos jaunuju mokslininky konferencijos „Lietuva be mokslo - Lietuva be ateities ", ivykusios Vilniuje 2003 m. kovo 30 d., pranešimu medžiaga. Aplinkos apsaugos inžinerija. Vilnius: Technika, 322-326.

Oškinis, V.; Kindurytė, R.; Butkus, D. 2004. Automobilių triukšmo tyrimų magistralèje Vilnius - Kaunas - Klaipeda rezultatai, Journal of Environmental Engineering and Landscape Management 12(1): 10-18.

Petraitis, E.; Januševičius, T. 2008. Study and assessment of transport noise in Panevèžys town, in 7-th International Conference "Environmental Engineering" Environmental protection section. Vilnius: Technika, 282-289.

Ustinavičienè, R.; Obelenis, V.; Ereminas, D. 2004. Dirbančiưu sveikata ir šiuolaikinès darbo sąlygos, Medicina 40(9): 897-904.

Vaišis, V.; Wolfgang, P.; Januševičius, T. 2008. Noise prediction research and modeling near Šiauliai railway station, in 7-th International Conference "Environmental Engineering" Environmental protection section. Vilnius: Technika, 416-422.

Vaišis, V.; Januševičius, T. 2008. Investigation and evaluation of noise level in the northern part of Klaipeda city, Journal of Environmental Engineering and Landscape Management 16(2): 89-96. doi:10.3846/1648-6897.2008.16.89-96

Vasarevičius, S.; Graudinyte, J. 2004. Transporto triukšmo lygio automobilių kelių ir geležinkelio sankirtose tyrimai ir įvertinimas, Journal of Environmental Engineering and Landscape Management 12(1): 19-24.

Žeromskas, R. 1998. Lietuvos kelių transporto svarbiausios aplinkosauginès charakteristikos, Aplinkos inžinerija [Environmental Engineering] 6(4): 140-145.

\section{TRIUKŠMO LYGIO PIETINĖJE PANEVĖŽIO DALYJE TYRIMAI IR VERTINIMAS}

\section{P. Baltrẻnas, E. Petraitis, T. Januševičius}

\section{Santrauka}

Triukšmas - ne tik Lietuvoje, bet ir visame pasaulyje aktuali problema. Automobilių srautams vis labiau didejjant, didejja ir jų keliamas triukšmas, ypač triukšmingi yra sunkvežimiai ir motociklai. Triukšmo tyrimai atlikti Panevěžio pietinėje dalyje prie pagrindinių gatvių. Matavimai vyko skirtingu paros laiku: dieną 6-18 val., vakare 18-22 val. ir naktị 22-6 valandomis. Šioje miesto dalyje pagrindine triukšmo priežastis - automobiliai. Triukšmo lygis, išmatuotas vietose, kuriose dažniausiai viršijamas, lyginamas su leidžiamosiomis normomis. Atlikta triukšmo lygių ir transporto srautų analizè. Iš duomenų matyti, kad leidžiamasis triukšmo lygis dieną viršytas $65 \%$, vakare $88 \%$, o nakti - $71 \%$ atliktų matavimų. Ekvivalentinis triukšmo lygis viršytas iki $14 \mathrm{dBA}$, o maksimalusis leidžiamasis - iki $17 \mathrm{~dB}$. Labiausiai triukšmo lygis viršijamas prie gatvių, kuriose pravažiuoja daugiausia automobilių.

Reikšminiai žodžiai: transporto triukšmas, triukšmas gyvenamojoje aplinkoje, leidžiamasis triukšmo lygis.

\section{ИССЛЕДОВАНИЕ И ОЦЕНКА УРОВНЯ ШУМА В ЮЖНОЙ ЧАСТИ ГОРОДА ПАНЕВЕЖИСА}

\section{П. Балтренас, Э. Петрайтис, Т. Янушявичюс}

Р е $з$ ю м е

Шум является актуальной проблемой не только в Литве, но и во всем мире. С увеличением автомобильных потоков неизбежно увеличивается и вызываемый ими (особенно грузовиками и мотоциклами) шум. Исследования шума проводились в южной части города Паневежиса, вблизи основных улиц в разное время суток: днем с 6 до 18 часов, вечером с 18 до 22 часов и ночью с 22 до 6 часов утра. В этой части города основным источником шума являются автомобили. Измеренные уровни шума были сравнены с допустимыми уровнями для мест, в которых он чаще всего превышен. Произведен анализ уровней шума и транспортных потоков. Из данных измерений видно, что допустимый уровень шума в дневное время был превышен в $65 \%$, вечером - в $88 \%$, а ночью - в $71 \%$ проведенных измерений. Эквивалентный уровень шума превышен до 14 дБа, а максимально допустимый - до 17 дБа. Уровни шума особенно увеличены вблизи улиц, по которым проезжает больше всего автомобилей.

Ключевые слова: транспортный шум, шум в жилой среде, допустимый уровень шума. 
Pranas BALTRÉNAS. Dr Habil, Prof. and head of Dept of Environmental Protection, Vilnius Gediminas Technical University.

Doctor Habil of Science (air pollution), Leningrad Civil Engineering Institute (Russia), 1989. Doctor of Science (air pollution), Ivanov Textile Institute (Russia), 1975. Employment: Professor (1990), Associate Professor (1985), senior lecturer (1975), Vilnius Civil Engineering Institute. Publications: author of 13 monographs, 24 study-guides, over 320 research papers and 67 inventions. Honorary awards and membership: prize-winner of the Republic of Lithuania (1994), a corresponding Member of the Ukrainian Academy of Technological Cybernetics, a full Member of International Academy of Ecological and Life Protection Sciences. Probation in Germany and Finland. Research interests: air pollution, pollutant properties, pollution control equipment and methods.

Egidijus PETRAITIS. Dr, Assoc. Prof., senior research worker, Dept of Environmental Protection, Vilnius Gediminas Technical University, Sauletekio al. 11, 10223 Vilnius, Lithuania.

Associate Professor, VGTU, 2004. Doctor of Science, VGTU, 2003. Master of Science, VGTU, 1999. Research interests: environmental protection, environmental management, air pollution, orimulsion influence.

Tomas JANUŠEVIČIUS. Master, doctoral student (2007), Dept of Environmental Protection, Vilnius Gediminas Technical University. Master of Science (environmental engineering), VGTU, 2007. Bachelor of Science (environmental engineering), ŠU, 2005. Publications: author of 3 scientific publications. 